\title{
PERFORMANCE OF LOCAL MAIZE CHOPPING MACHINE ATTACHED WITH FEEDING BELT
}

\author{
*Aboamera, M. A., *Mohamed, M. A., \\ *Gamea, G. R. and **Gomaa, E. M
}

\begin{abstract}
A transported belt was attached to a traditional chopping machine to improve its performance during the chopping process of maize. Evaluation the chopping performance focused upon changing machine rotational speed, moisture content of corn and feeding quantity. The highest actual chopping time was $14.16 \mathrm{sec}$ occurred at $1.56 \mathrm{~kg}$ of feeding quantity and $54.11 \%$ of corn moisture content at rate of 9.07 sec/kg. The highest rate of fuel consumption was $3.65 \mathrm{lit} / \mathrm{h} . \mathrm{kg}$. was observed at $73.45 \%$ of corn moisture content with $1.56 \mathrm{~kg}$ of feeding quantity. Maximum cutting efficiency (96.96\%) was occurred at $54.11 \%$ of corn moisture content at $0.67 \mathrm{~kg}$ of feeding quantity. The highest machine productivity $(2.55 \mathrm{ton} / \mathrm{h})$ was observed at $2000 \mathrm{rpm}$ of machine rotational speed with $1.56 \mathrm{~kg}$ of feeding quantity.
\end{abstract}

Keywords: modified chopping machine, mechanical chopping process of maize, actual time, maize chopping productivity, moisture content of maize during chopping process.

\section{INTRODUTION}

\begin{abstract}
$\mathrm{A}$ nimal feeding is one of the most serious problems facing animal producer and it can be solved by selecting the proper animal diet in the acceptable phase. A potentially serious economic problem in Egypt is the extreme shortage in animal feeds. Such problem appears to be growing rather than diminishing in magnitude or even stabilizing. conventional feeds are not entirely satisfactory because of their considerable high price. Moreover, green forage are only available in extremely low quantities in summer, and the conventional dry roughages are of limited quantities.
\end{abstract}

\footnotetext{
*Professor of Agric. Eng. Dept. Menofia University **Demonstrator of Agric. Eng. Dept. Menofia University
} 
Furthermore the present available animal feeds, in general, could hardly suffice the requirements of about $60 \%$ of the existing animal population (cattle, buffalo, sheep and goats). Thus, silage process was hoped to participate in solving the problem of feed shortage of livestock (Mohamed, et al. 1999)

Animal feedstuff is a very important aspect of livestock husbandry as it is a major limiting factor in the rearing of animals to meet the increasing demand for animal protein, milk, hides, and skin and other products (Adgidzi, 2007).

A drastic increase in animal body mass in the wet season, when there is abundant fresh grasses and abundant drinking water for the animals, can be noticed. However, in the dry season, when green grasses and water are not sufficient for the animals the resultant consequences is the loss in body mass, hence the little or no availability of milk and other diary products, and high cost of meat in the market, (Umanna and Agishi, 1988).

Extension dairy team (2012) stated that harvesting a crop that is too wet often results in a poor, undesirable fermentation and, in the case of upright silos, extensive nutrient loss in seepage. Material that is ensiled too dry is difficult to pack in bags, bunkers or piles, and the resulting oxygen within the silage mass will cause extensive nutrient loss and is prone to spoilage. The optimum moisture content for harvesting corn for silage depends on the storage structure utilized.

Morad et al (2007) showed that increasing feed rate of corn stalks from 0.810 to $1.032 \mathrm{ton} / \mathrm{h}$, decreased the percentage of cutting lengths of $(<5 \mathrm{~cm})$ from 65 to $40 \%$, while increased $(>10-15 \mathrm{~cm})$ from 10 to $20 \%$ and of $(>15-20 \mathrm{~cm})$ increased from 0 to $15 \%$. Increasing feed rate from 0.810 to 0.960 ton $/ \mathrm{h}$, decreased the percentage of cutting lengths of $(>5$ $10 \mathrm{~cm}$ ) from 25 to $20 \%$. Any further feed rate increase from 0.960 to $1.032 \mathrm{ton} / \mathrm{h}$, the percentage of cutting lengths of $(>5-10 \mathrm{~cm})$ will increase from 20 to $25 \%$, at constant rotating speed of $1550 \mathrm{rpm}$ and constant moisture content of $83 \%$. 
Lotfy (2003) reported that, the power consumption for cutting different residues was increased with increasing cutting and feeding speed. The minimum values of power consumption were (13.86, 15.24, and $15.66 \mathrm{~kW})$ noticed for cutting corn stalks, rice straw and cotton stalks respectively at $24.08 \mathrm{~m} / \mathrm{s}$ cutting speed and $1.0 \mathrm{~m} / \mathrm{s}$ feeding speed. The maximum values of power consumption were ( $22.97,23.92$ and $25.82 \mathrm{~kW}$ ) for cutting corn stalks, rice straw and cotton stalks respectively at $43.35 \mathrm{~m} / \mathrm{s}$ cutting speed and 2.5 $\mathrm{m} / \mathrm{s}$ feeding speed.

Younis et al. (2002) developed a chopping machine and used it for cutting residues of rice, cotton and maize. They reported that the maximum required power and consumed energy, (11.77 kW and 12.99 $\mathrm{kW} . \mathrm{h} /$ ton), were found at rotor speed 2200 and $1600 \mathrm{rpm}$ respectively. Increasing of rotor speed from 1600 to $2000 \mathrm{rpm}$ caused a decrease in consumed energy by $17.11 \%$. While increasing of rotor speed from 2000 to $2200 \mathrm{rpm}$ caused an increase in consumed energy by $12.9 \%$.

El-Sisi (2012) stated that the cutting efficiency increased with increasing cutting drum speed for cotton stalks, that is due to an increase in the number of cuts per time unit and this increase the weight of the suitable cutting length. The cutting efficiency increased from $85.72 \%$ to $97.77 \%$ with increasing cutting speed from $1200 \mathrm{rpm}$ to $2000 \mathrm{rpm}$ at $8 \%$ moisture content. Also increasing the cutting drum speed from 1200 to $2000 \mathrm{rpm}$ increased the cutting efficiency from $(85.72,83.5$ and $81.85 \%)$ to $(97.77,95.43$ and $93.87 \%)$ at 8,10 and $12 \%$ moisture content, respectively.

El-Ashry et al., (2004) stated that chopping efficiency for maize crop residues increased as knife rotating speed increased from 520 to $920 \mathrm{rpm}$. At the same time, the chopping efficiency decreased by increasing both of forward speed from 0.9 to $4.5 \mathrm{~km} / \mathrm{h}$. and straw average moisture content from 12.20 to $21.65 \%$.

Mohamed (2007) stated that increasing rotating speed from 1250 to $1550 \mathrm{rpm}$ ( 41.23 to $51.13 \mathrm{~m} / \mathrm{s}$ ) at constant feed rate of $1.032 \mathrm{ton} / \mathrm{h}$ and constant moisture content of $83 \%$ for corn stalks, increased hourly cost from 25.06 to $26.3 \mathrm{LE} / \mathrm{h}$ and operational cost from 24.28 to $25.48 \mathrm{LE} /$ ton. 
Increasing feed rate from 0.810 to $1.032 \mathrm{ton} / \mathrm{h}$ at constant rotating speed of $51.13 \mathrm{~m} / \mathrm{s}$ and constant moisture content of $83 \%$, increased hourly cost from 25.23to26.33 LE/h while decreased operational cost from 31.15 to 25.51 LE/ton. Increasing residues moisture content from 10 to $32 \%$ at constant rotating speed of $\mathrm{m} / \mathrm{s}$ and constant feed rate of 1.032 ton $/ \mathrm{h}$ decreased hourly cost from 25.87 to $25.55 \mathrm{LE} / \mathrm{h}$ and operational cost from 25.07 to $24.76 \mathrm{LE} /$ ton Increasing moisture content more than $32 \%$ up to $83 \%$, hourly cost will increase from 25.55 to $26.3 \mathrm{LE} / \mathrm{h}$ and operational cost from 24.76 to $24.48 \mathrm{LE} /$ ton.

Ibrahim (2006) Pointed out that machine production increased with increasing the cutting speed for cutting maize stalks. For example the machine production was $0.82,1.08,1.13,1.35$ and 1.8 ton/h with increasing cutting speed from 1200, 1400, 1600, 1800 and $2000 \mathrm{rpm}$ at $10.10 \%$ moisture content and $35^{\circ}$ cutting edge angle. Machine production decreased from 2.14 ton/h to 1.34 ton/h with increasing cutting edge angle from $25^{\circ}$ to $45^{\circ}$ degree at $10.10 \%$ moisture content and $2000 \mathrm{rpm}$ cutting speed. The minimum value of machine production was $0.75 \mathrm{ton} / \mathrm{h}$ at 1200 rpm cutting speed and $25^{\circ}$ cutting edge angle and $65.6 \%$ moisture content while, the maximum value of machine production was $2.14 \mathrm{ton} / \mathrm{h}$ at 2000 rpm cutting speed $25^{\circ}$ cutting edge angle and $10.10 \%$ moisture content. The machine production were affected by cutting drum speed, cutting edge angle and feeding drum speed.

The main objective of this study was to evaluate the performance of both local and modified maize chopping machines from the point of view of actual chopping time, required fuel consumption, cutting efficiency and productivity. In addition to drive the effect of the transported belt as a procedure in improving the chopping process.

\section{MATERIAL AND METHODS}

Maize (Zea mays), was harvested and the average measured physical characteristics of each plant were as follows:

average stem diameter $22.205 \mathrm{~mm}$, average length of stem $250.3 \mathrm{~cm}$ average ear diameter $51.7655 \mathrm{~mm}$ and average ear length $30.835 \mathrm{~cm}$. 


\section{Chopping machine}

The cutting machine, that used in this work, was presented schematically in elevation and side view in fig. (1). The main equipment which used in this work was chopper machine.

The used chopping machine operated by tractor:

Tractor of four wheel and standard type of $90 \mathrm{HP}(66.18 \mathrm{~kW})$ power was used. The machine was connecting to the tractor and the power transmitted through the transmission system.

\section{Studied factors}

The study focused and concerned with the effect of changing three main factors which were; feeding quantity, cutting speed and corn moisture content during the chopping process with both modified and non modified machines.

\section{(a) Feeding quantity}

Three different levels of corn feeding quantity were used $(0.67,1.12$ and $1.56 \mathrm{~kg}$ ). These values were computed according to the average wet mass of each plant at three levels of corn moisture content which were 54.11, 64.19 and $73.45 \%$ respectively. A large sample (2700 plants) were considered and the average dry mass $(0.223 \mathrm{~kg})$ was obtained. Due to this value, the feeding quantity of corn was calculated for 3, 5 and 7 corn plant and was $0.67,1.12$ and $1.56 \mathrm{~kg}$ respectively.

\section{(b) Cutting speed}

Five different levels of cutting speed were changed which were 1200, 1400, 1600, 1800 and $2000 \mathrm{rpm}$. Table (1) represents the values of the knives rotational speed and the corresponding values of the feeding drum speed. The values of the corresponding speeds were calculated according to the value of the transmission ratio of the gear box used in transfer the rotational speed to all moved member of the chopping machine.

\section{(c) Corn moisture content}

Three levels of corn moisture content were considered. Between each two consecutive levels, three days were left and the moisture content of corn was measured. The values of the tested corn moisture content were $73.45,64.19$ and $45.11 \%$. 


\begin{tabular}{|c|c|c|c|c|c|c|c|c|}
\hline 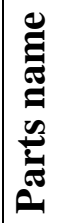 & 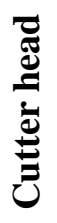 & 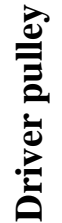 & 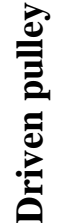 & 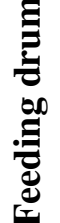 & 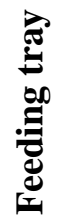 & $\stackrel{\bar{E}}{0}$ & $\underset{\sum}{\Xi}$ & 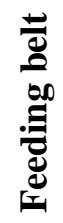 \\
\hline$\stackrel{0}{Z}$ & - & $N$ & $m$ & $\nabla$ & in & 6 & $N$ & $\infty$ \\
\hline
\end{tabular}

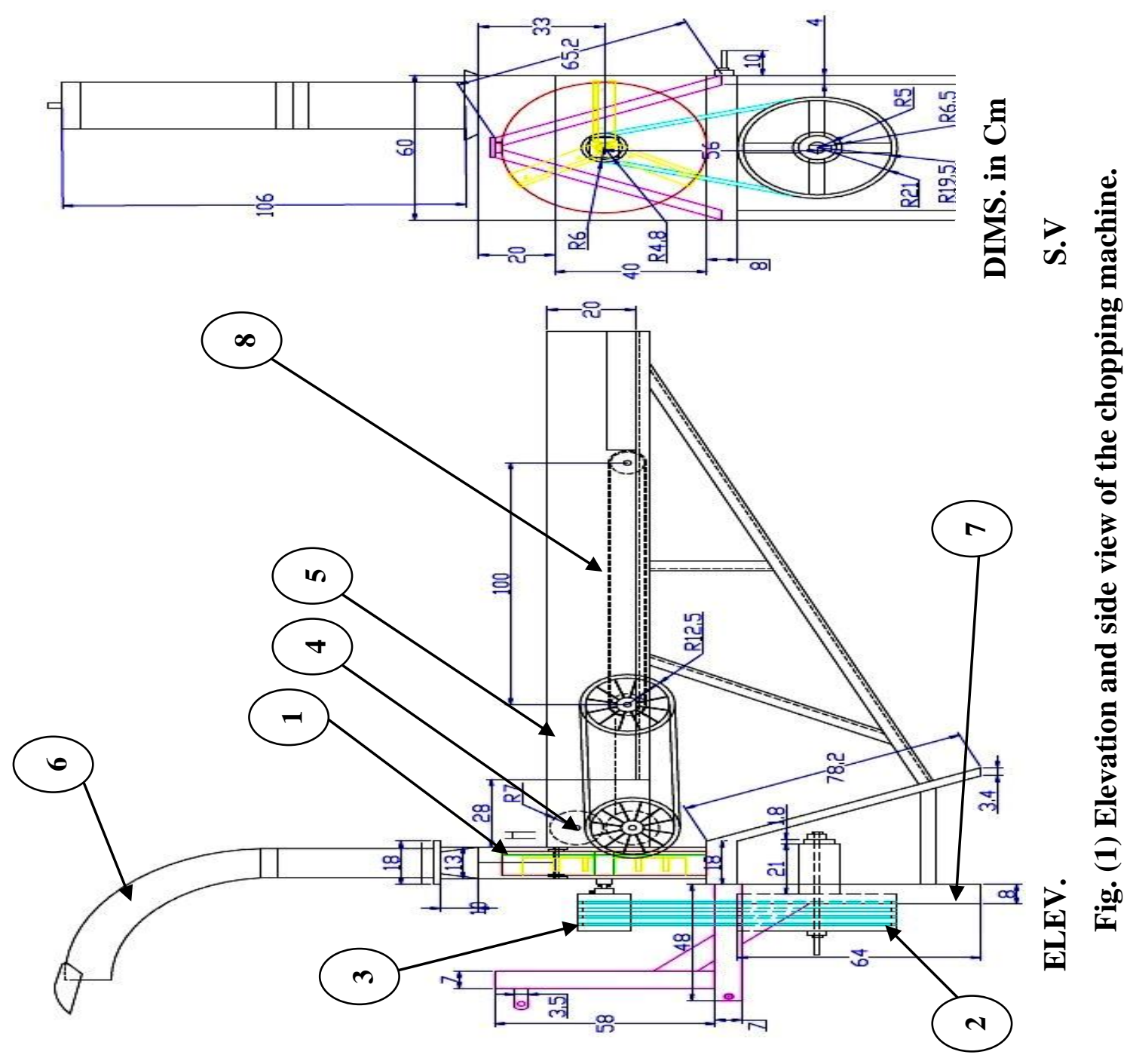


Table 1: Corresponding values of feeding drum speed and belt drum speed at different levels of rotational speed of knives.

\begin{tabular}{|c|c|c|c|c|c|}
\hline \multirow{2}{*}{ Item } & \multicolumn{5}{|c|}{ Rotational speed of knives (rpm) } \\
\cline { 2 - 6 } & $\mathbf{1 2 0 0}$ & $\mathbf{1 4 0 0}$ & $\mathbf{1 6 0 0}$ & $\mathbf{1 8 0 0}$ & $\mathbf{2 0 0 0}$ \\
\hline $\begin{array}{c}\text { Speed of } \\
\text { feeding drum } \\
\text { (rpm) }\end{array}$ & 48 & 56 & 64 & 72 & 80 \\
\hline $\begin{array}{c}\text { Speed of drum } \\
\text { belt (rpm) }\end{array}$ & 48 & 56 & 64 & 72 & 80 \\
\hline $\begin{array}{c}\text { Forward speed } \\
\text { of feeding } \\
\text { drum m/min }\end{array}$ & 21.12 & 24.64 & 28.16 & 31.68 & 35.20 \\
\hline $\begin{array}{c}\text { Forward speed } \\
\text { of feeding belt } \\
\text { m/min }\end{array}$ & 13.56 & 15.83 & 18.09 & 20.35 & 22.61 \\
\hline
\end{tabular}

\section{Measuring instruments}

Many measuring devices were used in evaluating the affected parameters. These devices were:

\section{(a) Digital balance}

Two kind of digital balance were used, one was used for determining the mass of samples of chopping corn plant with $0.01 \mathrm{~g}$ accuracy and $5 \mathrm{~kg}$ maximum reading and the other was used for determining the weight of the whole plant before chopping with $10 \mathrm{~g}$ accuracy and $40 \mathrm{~kg}$ maximum reading.

\section{(b) Drying oven}

An Electrical drying oven was used to dry the samples of corn plant in order to calculate the corn moisture content. The operating power of the drying oven is $1.2 \mathrm{~kW}$ and has a temperature range 5 to $240 \mathrm{c}$ with $1 \mathrm{c}$ adjust ment accuracy.

\section{(c) Rotational speed of the rotating shaft}

The velocity of the rotating shaft was measured by means of a multirange tachometer. It gives the rotational terms of velocity in rpm.

\section{Calculation of the affected variables}

\section{Corn moisture content (M.C)}

Plant samples were dried at $105^{\circ} \mathrm{C}$ for $24 \mathrm{~h}$ using the electrical oven. The samples were weighted before and after drying and the corn moisture content (wet base) in (\%) was determined using the following equation (AOAC, 1990): 


$$
\text { M.C. }=\frac{S B-S A}{S B} \times 100
$$

Where:

$$
\begin{aligned}
& \text { M.C.= Corn moisture content }(\%) ; \\
& \text { SB = Sample mass before drying (g); and } \\
& \text { SA = Sample mass after drying (g). }
\end{aligned}
$$

\section{Machine productivity}

The machine productivity of the chopping machine was calculated by dividing the output mass by the operating time of the chopping machine>

\section{Cutting efficiency}

Cutting length of the final product is an important parameter to evaluate the performance of the cutting process. Where, the suitable cutting length (Lc) that can be used to produce compost and the forage is in the range of $0<\mathrm{Lc}<50 \mathrm{~mm}$. Standard sieves that used for segregation a specific mass, $(\mathrm{Sb})$ from the chopped production to several mass, having cutting length $0<\mathrm{Lc}<50 \mathrm{~mm}$. Consequently, the cutting efficiency $\left(\eta_{\mathrm{c}}\right)$ in $(\%)$ can be calculated as follows:

$$
\eta_{c}=\frac{\mathrm{Sa}}{\mathrm{Sb}} * 100
$$

Where:

$$
\begin{aligned}
\eta_{c} & =\text { Cutting eficiency }(\%) ; \\
S_{b} & =\text { Mass of the chopped production before segregation, }(\mathrm{g}) ; \text { and } \\
S_{a} & =\text { Mass of the chopped production after segregation of cutting } \\
& \text { length } 0<\mathrm{Lc}<50 \mathrm{~mm},(\mathrm{~g}) .
\end{aligned}
$$

\section{$\underline{\text { Required power }}$}

The required power for chopping process was calculated using the following equation (Embaby, 1985)

$$
\frac{F C \times \rho_{r} \times L . C . V \times \eta_{m} \times \eta_{t h}}{3600}
$$

Where:

$\mathrm{EP}=$ Required power during the chopping process $(\mathrm{kW}) ;$ 
$\mathrm{FC}=$ Fuel consumption $(\mathrm{L} / \mathrm{h})$;

$\rho_{\mathrm{r}}=$ Density of the fuel $(0.85 \mathrm{~kg} / \mathrm{L})$;

L.C.V = Lower calorific value of fuel $(41868 \mathrm{~kJ} / \mathrm{kg})$;

$\eta_{\mathrm{m}}=$ Mechanical efficiency of engine, $80 \%$; and

$\eta_{\text {th }}=$ Thermal efficiency of the engine, (considered to be about $40 \%$ for diesel engine).

\section{Energy consumption}

Estimation of the consumed energy was carried out using the following equation:

$$
E C=\frac{E p}{p}
$$

where:

$\mathrm{EC}=$ Energy consumption $(\mathrm{kW} \cdot \mathrm{h} / \mathrm{ton})$;

$\mathrm{Ep}=$ Required power $(\mathrm{kW})$; and

$\mathrm{p}=$ Machine productivity (ton/h)

\section{RESULTS AND DISCUSSION}

\section{Actual chopping time}

At each level of feeding quantity of corn, the actual consumed time was measured for both modified and non modified chopping machines. The measured time was recorded at the different levels of rotational speed of knives. In general at each rotational speed, the time of chopping increased with increasing feeding quantity of corn. While at each feeding quantity the actual time decreased with increasing rotational speed of knives. Increasing corn moisture content led to decrease the chopping time at each tested speed of knives.

For the modified machine the highest actual time (14.16 sec) was occurred with $1.56 \mathrm{~kg}$ of feeding quantity with a rate of $9.07 \mathrm{sec} / \mathrm{kg}$ and $54.11 \%$ of corn moisture content at $1200 \mathrm{rpm}$ of rotational speed of knives. The lowest actual time $(3.72 \mathrm{sec})$ was observed with $0.67 \mathrm{~kg}$ of feeding quantity with a rate of $4.68 \mathrm{sec} / \mathrm{kg}$ and $73.45 \%$ of corn moisture content at $2000 \mathrm{rpm}$ of rotational speed of knives. Fig(2) illustrates the relationship between the rotational speed of knives for the modified 
chopping machine and the actual time through the chopping process at the three levels of corn moisture content and feeding quantity.

For the non modified machine the highest actual time $(14.79 \mathrm{sec})$ was observed with $1.56 \mathrm{~kg}$ of feeding quantity with a rate of $9.48 \mathrm{sec} / \mathrm{kg}$ and $54.11 \%$ of corn moisture content at $1200 \mathrm{rpm}$ of rotational speed of knives. The lowest actual time $(6.13 \mathrm{sec})$ was occurred with $0.67 \mathrm{~kg}$ of feeding quantity with a rate of $9.15 \mathrm{sec} / \mathrm{kg}$ and $73.45 \%$ of corn moisture content at $2000 \mathrm{rpm}$ of rotational speed of knives. Fig (3) illustrates the relationship between the rotational speed of knives for the non modified machine and the actual time through the chopping process at the three level of corn moisture content and feeding quantity.
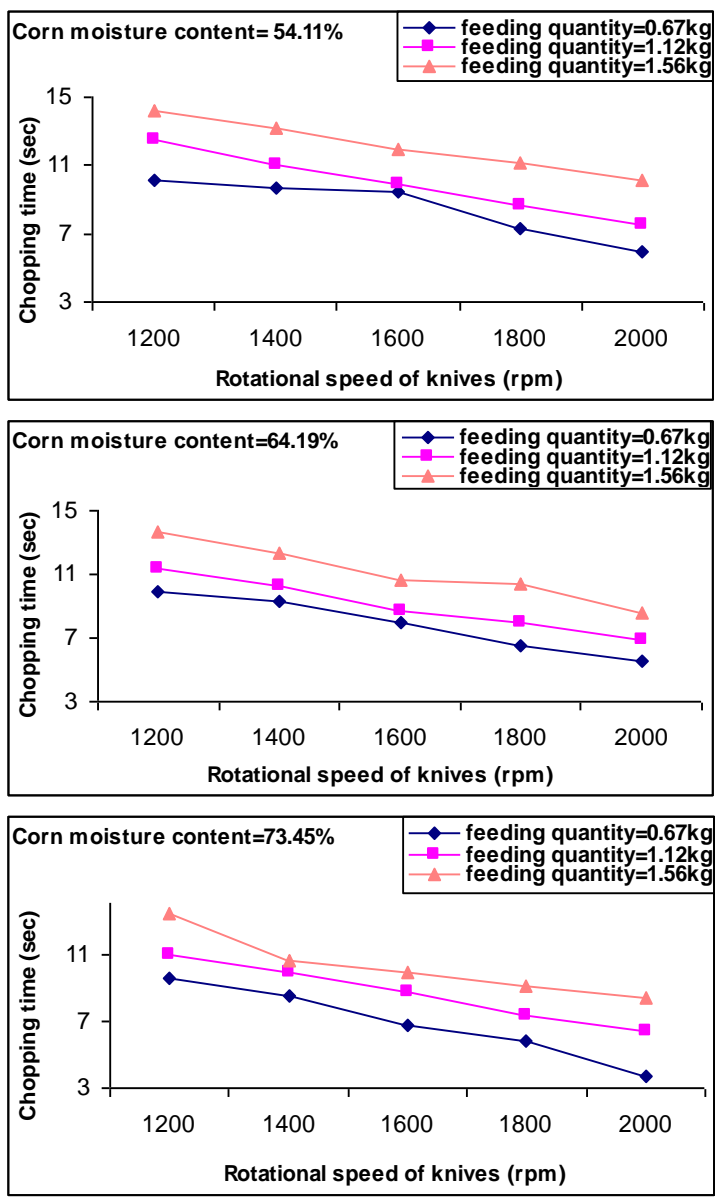

Fig (2): Chopping time at different levels of rotational speed of knives and different levels of dry feeding quantity for modified chopping machine
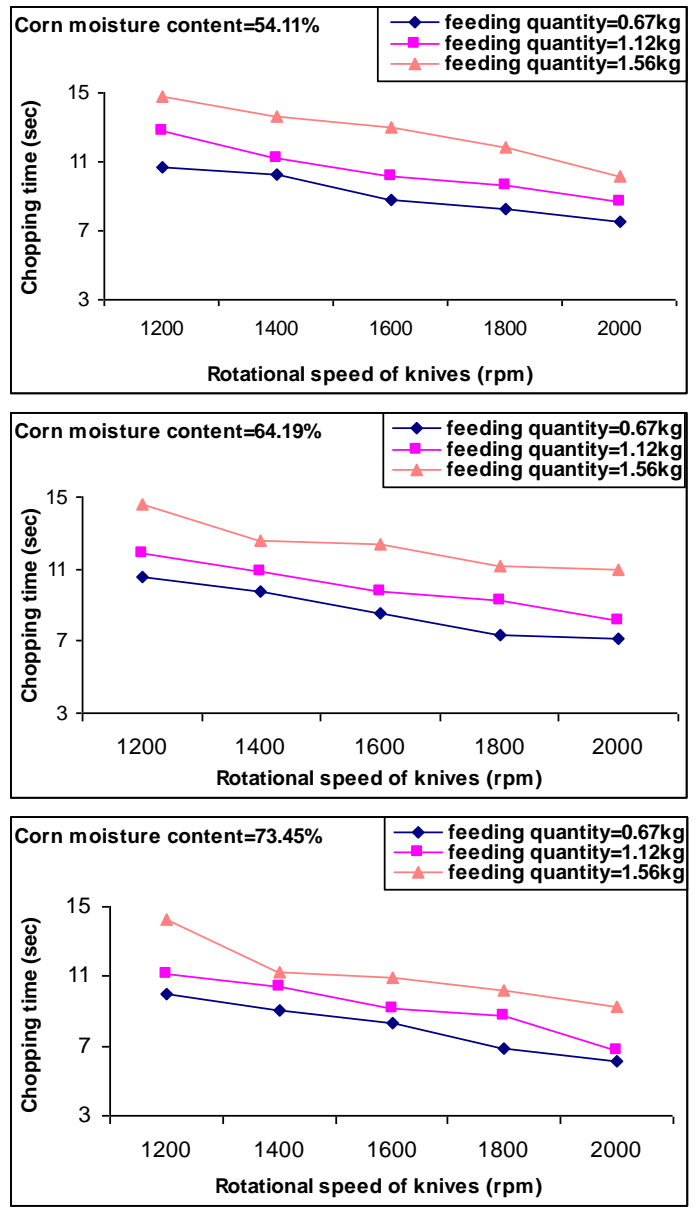

Fig (3): Chopping time at different levels of rotational speed of knives and different levels of dry feeding quantity for non modified chopping machine 


\section{Fuel consumption}

At each level of feeding quantity the fuel consumption increased with increasing the rotational speed of knives. Also increasing the feeding quantity led to increase the fuel consumption. Increasing the corn moisture content led to increase the required fuel at all levels of the knives rotational speed. All of this for the modified and non modified chopping machine.

For the modified machine the highest fuel consumption occurred at $73.45 \%$ of corn moisture content $5.70 \mathrm{lit} / \mathrm{h}$ with $1.56 \mathrm{~kg}$ of corn feeding quantity and $2000 \mathrm{rpm}$ of knives rotational speed. Hence, the highest rate of fuel consumption was $3.65 \mathrm{lit} / \mathrm{h}$. $\mathrm{kg}$. The lowest fuel consumption (1.80 lit/h) was observed at $54.11 \%$ of corn moisture content with 0.67 $\mathrm{kg}$ of feeding quantity and $1200 \mathrm{rpm}$ of knives rotational speed i.e the lowest rate of fuel consumption was $2.69 \mathrm{lit} / \mathrm{h}$. kg. Fig.(4) showed the changed of fuel consumption with for the modified machine at the different levels of rotational speed of knives.

For the non modified machine the highest value of fuel consumption was $6.00 \mathrm{lit} / \mathrm{h}$ occurred at $73.45 \%$ of corn moisture content with $1.56 \mathrm{~kg}$ of feeding quantity (i.e $3.85 \mathrm{lit} / \mathrm{h}$. kg) and $2000 \mathrm{rpm}$ of knives rotational speed. Fig.(5) illustrates the variation of the fuel consumption according to due to changing rotational speed of knives.

\section{cutting efficiency}

For the modified machine and non modified machine, increasing the rotational speed of knives led to increase the cutting efficiency at all levels of corn moisture content and feeding quantity. Also increase both the moisture content of corn and feeding quantity led to decrease the cutting efficiency at each level of corn moisture content and each level of knives rotational speed.

For the modified machine the highest cutting efficiency $(96.96 \%)$ was observed with $2000 \mathrm{rpm}$ of the rotational speed of knives and $54.11 \%$ of corn moisture content at $0.67 \mathrm{~kg}$ of feeding quantity. The lowest cutting efficiency was 84.92 occurred at $73.45 \%$ of corn moisture content with $1.56 \mathrm{~kg}$ of corn feeding quantity and 1200rpm of knives rotational speed. Fig.(6) represents the relationship between the rotational speed of knives for the modified chopping machine and the cutting efficiency. 

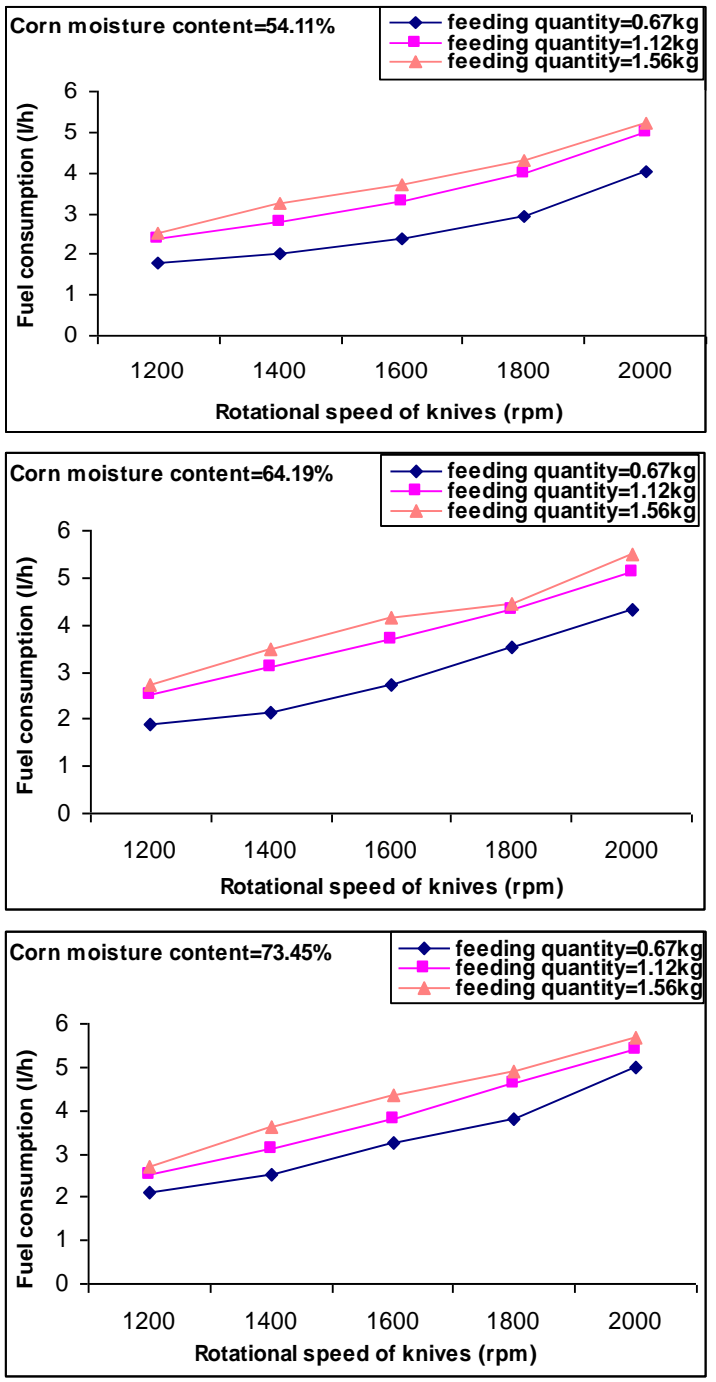

Fig (4): Fuel consumption at different levels of rotational speed of knives and different levels of dry feeding quantity for modified machine
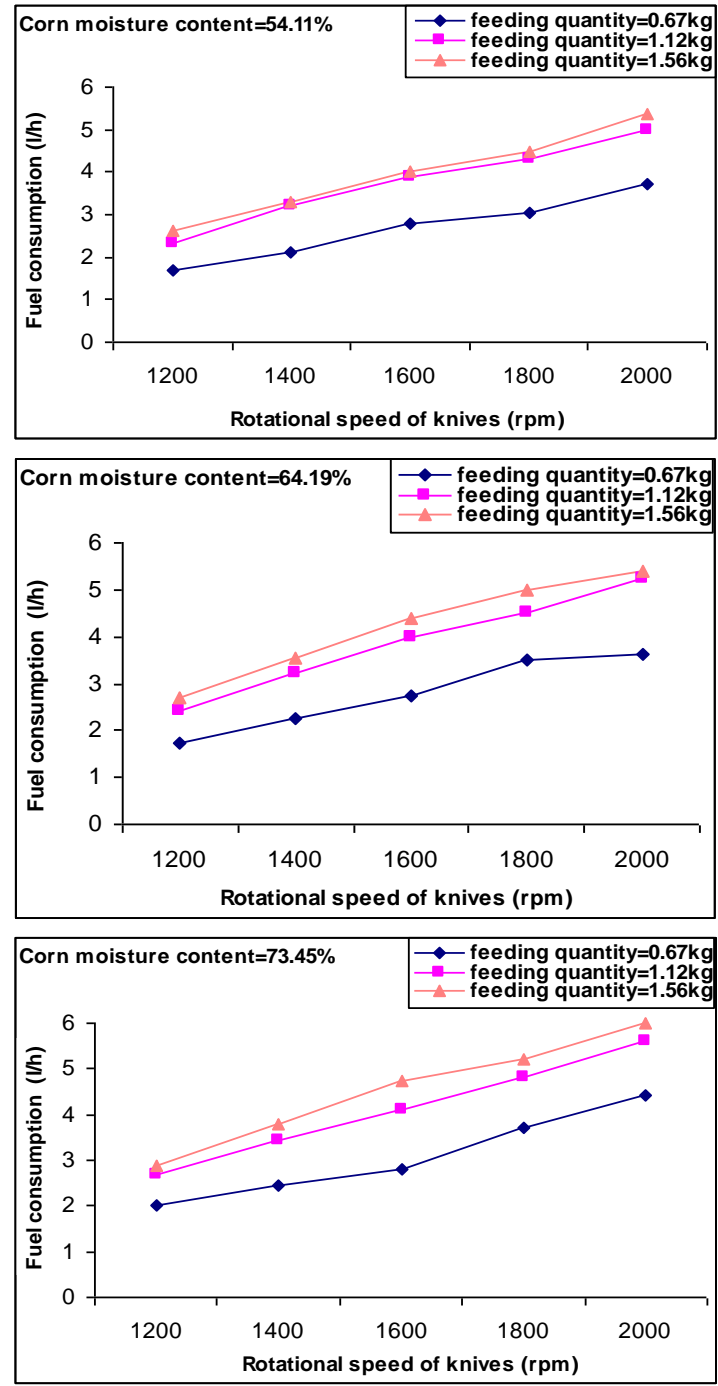

Fig (5): Fuel consumption at different levels of rotational speed of knives and different levels of dry feeding quantity for non modified machine

For the non modified machine the highest cutting efficiency $(93.37 \%)$ was occurred with $2000 \mathrm{rpm}$ of knives rotational speed and $0.67 \mathrm{~kg}$ of feeding quantity at $54.11 \%$ of corn moisture content. The lowest cutting efficiency occurred at $73.45 \%$ of corn moisture content was $83.84 \%$ with $1.56 \mathrm{~kg}$ of feeding quantity and $1200 \mathrm{rpm}$ of knives rotational speed. 
Fig.(7) showed the cutting efficiency for the non modified chopping machine due to changing the rotational speed of knives.
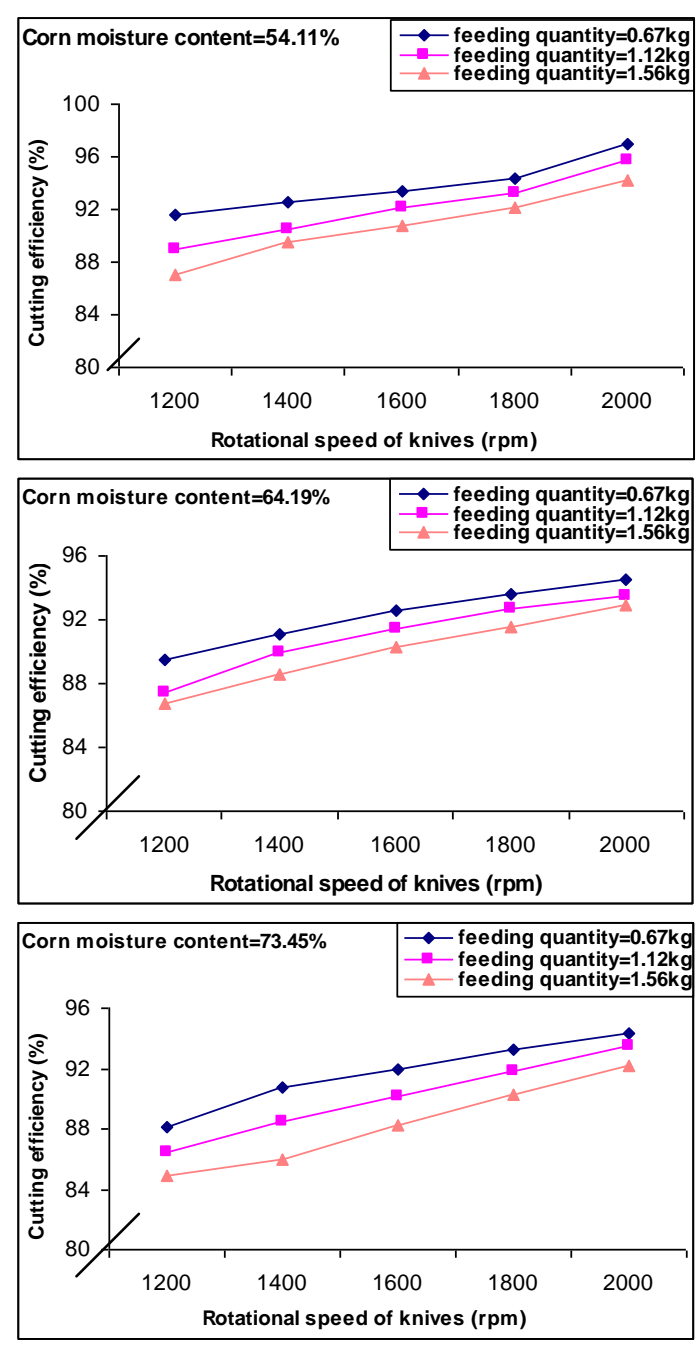

Fig(6): Cutting efficiency at different levels of rotational speed of knives and different levels of dry feeding quantity at the three levels of moisture content for the modified machine.
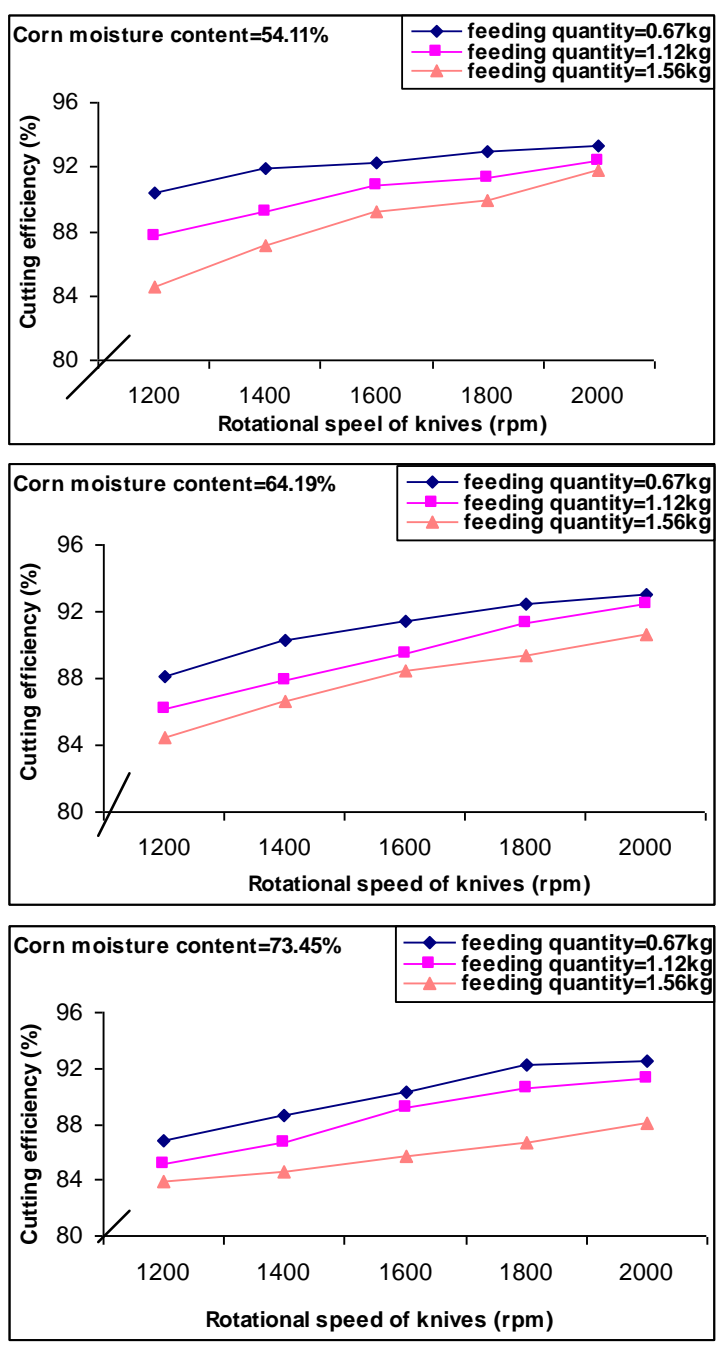

Fig(7): Cutting efficiency at different levels of rotational speed of knives and different levels of dry feeding quantity at the three levels of moisture content for the non modified machine.

\section{chopping energy}

The chopping energy increased with increasing the rotational speed of knives at each feeding quantity except when increasing from 1800 to 
$2000 \mathrm{rpm}$ with $0.67 \mathrm{~kg}$ of feeding quantity at $73.45 \%$ and from 1800 to $2000 \mathrm{rpm}$ with $1.12 \mathrm{~kg}$ of feeding quantity at $73.45 \%$ of corn moisture content for modified and non modified chopping machine respectively. At each level of corn moisture content, the chopping energy decreased with increasing the feeding quantity at each level of the rotational speed. Also increasing corn moisture content led to decrease the chopping energy at each level of corn feeding quantity.

For the modified machine the highest chopping energy (14.42 $\mathrm{kW} . \mathrm{h} / \mathrm{ton}$ ) was observed with $54.11 \%$ of corn moisture content at $0.67 \mathrm{~kg}$ of feeding quantity and $2000 \mathrm{rpm}$ of knives rotational speed. The lowest chopping energy $(5.42 \mathrm{~kW} . \mathrm{h} / \mathrm{ton})$ was occurred with $73.45 \%$ of corn moisture content at 1.56 of feeding quantity and $1200 \mathrm{rpm}$ of knives rotational speed. Fig.(8) showed the changing of the chopping energy according to the values of the rotational speed of knives for the modified machine.

For the non modified machine the highest chopping energy (16.53 $\mathrm{kW} . \mathrm{h} / \mathrm{ton}$ ) was observed with $54.11 \%$ of corn moisture content at 0.67 $\mathrm{kg}$ of feeding quantity and $2000 \mathrm{rpm}$ of knives rotational speed. The lowest chopping machine $(6.17 \mathrm{~kW} . \mathrm{h} / \mathrm{ton})$ was occurred with $73.45 \%$ of corn moisture content at 1.56 of feeding quantity and $1200 \mathrm{rpm}$ of knives rotational speed. Fig.(9) illustrates the variation of the chopping energy according to the value of the rotational speed of knives for the non modified machine.

The machine productivity in (ton/h) considered an important operating parameter which used in evaluating the efficient performance of the chopping machine. For both of modified and non modified chopping machine, increasing the rotational speed of knives in (rpm), corn moisture content in $(\%)$ and feeding quantity in $(\mathrm{kg})$ led to increase the machine productivity.

For the modified machine the highest productivity occurred at $73.45 \%$ of corn moisture content was $2.55 \mathrm{ton} / \mathrm{h}$ with $1.56 \mathrm{~kg}$ of feeding quantity and $2000 \mathrm{rpm}$ of knives rotational speed. The lowest productivity was $0.52 \mathrm{ton} / \mathrm{h}$ occurred at $54.11 \%$ of corn moisture content with $0.67 \mathrm{~kg}$ of feeding quantity and $1200 \mathrm{rpm}$ of knives rotational speed. Fig.(10) represents the relationship between the rotational speed of knives for the modified machine and the productivity. 

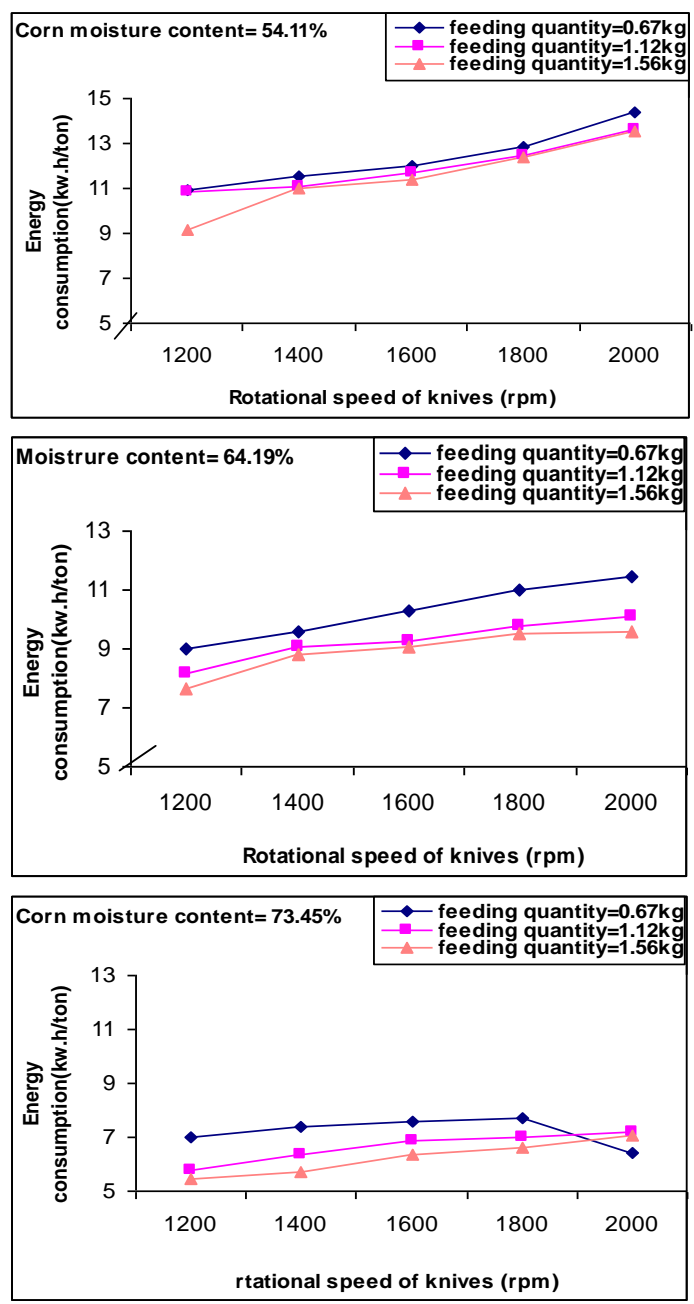

Fig(8): Chopping energy at different levels of rotational speed of knives and different levels of dry feeding quantity at the three levels of moisture content for the modified machine.
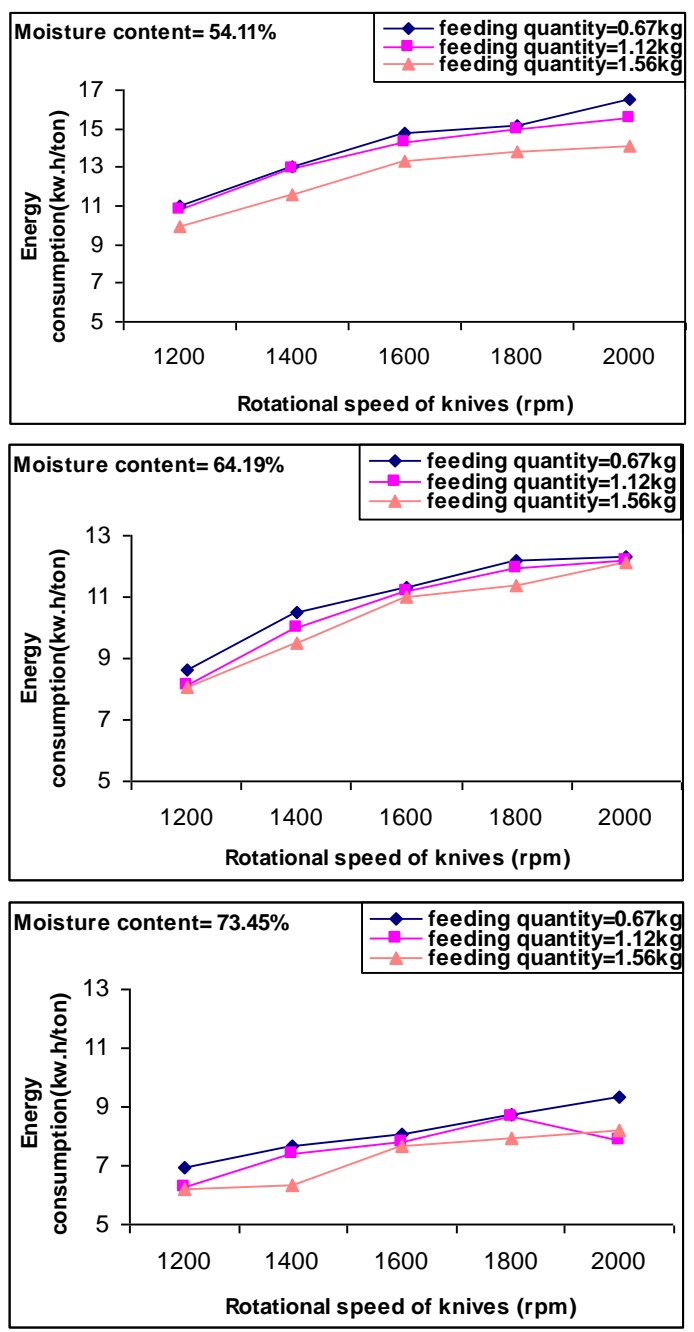

Fig(9): Chopping energy at different levels of rotational speed of knives and different levels of dry feeding quantity at the three levels of moisture content for the non modified machine.

For non modified machine the highest productivity $(2.32$ ton/h) was observed with $73.45 \%$ of corn moisture content at $0.67 \mathrm{~kg}$ of feeding quantity and $1200 \mathrm{rpm}$ of the rotational speed of knives. The lowest productivity $(0.49$ ton/h) was observed with $54.11 \%$ of corn moisture content at $0.67 \mathrm{~kg}$ of feeding quantity and $1200 \mathrm{rpm}$ of knives rotational speed. Fig.(11) illustrates that for the non modified machine the effect of changing the rotational speed of knives on the productivity. 

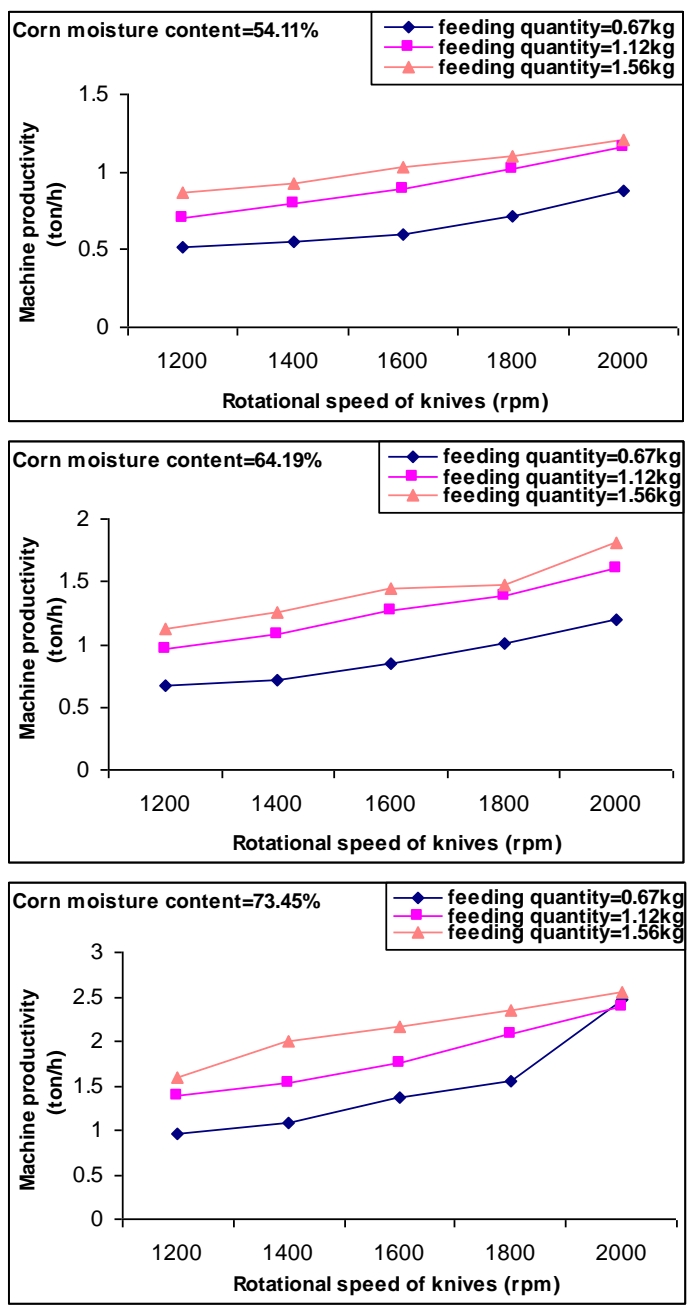

Fig(10): Machine productivity at different levels of rotational speed of knives and different levels of dry feeding quantity at the three levels of moisture content for the modified machine
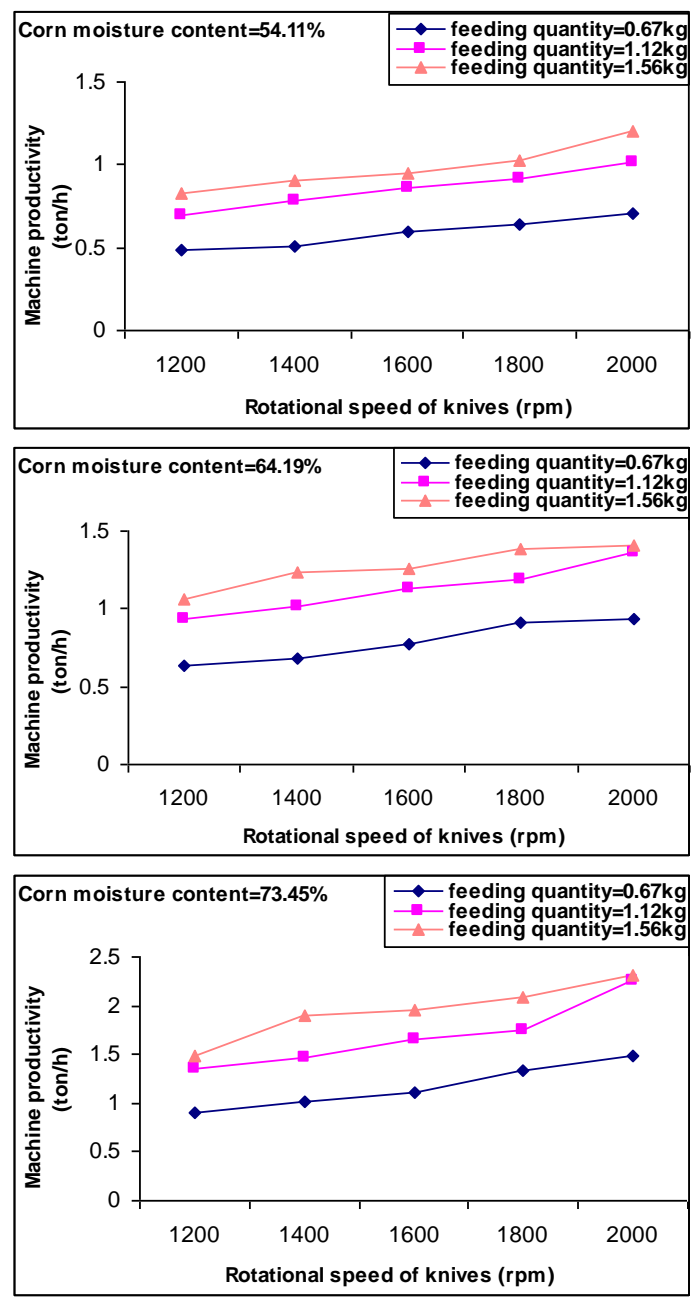

Fig(11): Machine productivity at different levels of rotational speed of knives and different levels of dry feeding quantity at the three levels of moisture content for the non modified machine.

\section{CONCLUSION}

The obtained results concluded the following procedures:

1- carrying out the chopping process for corn using the modified machine included a transported belt because of the higher factor of safety and less dangerous exist. 
2- Operating the modified at higher level of rotational speed of knives because of lower actual chopping time and lower rate of fuel consumption that obtained with modified machine.

3- Operating the chopping process with the low level of corn moisture content.

4- For having higher cutting efficiency, it recommended using the modified machine at the lower level of rotational speed and lower level of corn moisture content.

5- The values of the obtained productivity concluded using the modified machine at all levels of both corn moisture content and feeding quantity.

6- The lowest actual chopping time(3.72sec) was observed with the modified machine at $2000 \mathrm{rpm}$ of knives rotational speed, $0.67 \mathrm{~kg}$ of feeding quantity and $73.45 \%$ of corn moisture content.

7- The lowest value of fuel consumption was $1.7 \mathrm{lit} / \mathrm{h}$ occurred at $54.11 \%$ of corn moisture content with $0.67 \mathrm{~kg}$ of feeding quantity and 1200 rpm of knives rotational speed for the non modified machine.

8- The best chopping efficiency occurred at $54.11 \%$ of corn moisture content was $96.96 \%$ with $0.67 \mathrm{~kg}$ of corn feeding quantity and 2000 rpm of knives rotational speed for the modified machine.

9- The highest productivity $(2.55 \mathrm{Mg} / \mathrm{h})$ was observed with the modified machine at $2000 \mathrm{rpm}$ of knives rotational speed, $1.56 \mathrm{~kg}$ of feeding quantity and $73.45 \%$ of corn moisture content.

\section{REFERENCES}

Adgidiz, (2007) "Development and performance evaluation of a forage chopper". Journal of Agricultural Engineering and Technology (LAET). Federal University of Technology, Minna, Niger state, Nigeria. volume 15, 2007. P .P. 12-24.

AOAC (1990) "Association official Analytical chemists". $15^{\text {th }}$ edn. Washington Dc, U.S.A

El-Ashry. A. S.; E. H. Musa; and I. S. Yousef(2004) Development of a combination unit for cutting and chopping corn stalks during harvesting. Misr J. Ag. Eng., 21 (3): 685-696. 
El-Sisi, S. F. B (2012). Some engineering factors affecting handling of residuals and its relation to environment. M. Sc. thesis, Menofia Univ., Agric. Eng. Department. June 2012. P.P. 1-129.

Embaby, A. T. (1985) "A comparison of the different mechanization systems for cereal crop production". M.Sc thesis, Faculty of Agriculture., Cairo University.

Extension dairy team (2012). Making quality corn silage. Iowa State University, Iowa Beef Center. P.P, 1:3.

Ibrahim, A. A. (2006) Study of some engineering factors affecting the performance of a machine for cutting field residues. M. Sc. thesis, Menofia Univ. Agric. Eng. Department. 2006. P.P. 1-142.

Lotfy, A. (2003) "Development and performance evaluation a machine for cut and throw agricultural residues". Misr, J.AG. Eng., 20(3): 724-736.

Mohamed, H. I. A (2007). Effect of mechanical chopping and adding different farm residues on soil physical properties and wheat yield. M. Sc. thesis, Zagazig Univ., Agric. Eng. Department. P.P. 1-85.

Mohamed, M.A. ; G.H, El-Sayed ; and K.E.S.Hegazy (1999). Some factors affecting power and energy requirements for forage harvesster. Msr. J. Ag. Eng., 16(4), October, 1999.

Morad, M. M. ; M. A. Arnaout ; O. A. Omar ; and H. I. Ahmed (2007) "Effect of mechanical chopping and adding different farm residues on soil physical properties and wheat yield" Zagazig J. Agric. Res., Vol. 34 No. (4) pp. 781-804.

Umunna, N. N. and Agishi, E. C.( 1988 ) "Nutritive value of savanna grasses and harvest residues for use in dry season animal feeding". Invited paper at the scrub savannah studies symposium.

Bauchi, Nigeria. February, $7-8,1988$.

Younis, S. M.; M. I. Ghonimy.; M. A. Baiomy.; and T. H. Mohamed (2002) "Techno-economic evaluation of a developed field crop residues chopper". Misr, J.AG.Eng, 19(4): 63-80. 


\section{الملخص العربيى}

\section{أداء آلة تقطيع نبات الذرة متصل بها سبير تغذية

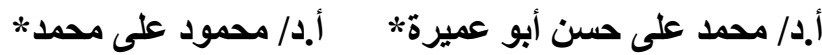

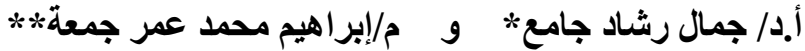

أجريت هذه الدر اسـة بورشـة كليـة الزر اعـة بشبين الكوم التابعـة لقسم الهندسـة الزر اعيـة بكليـة

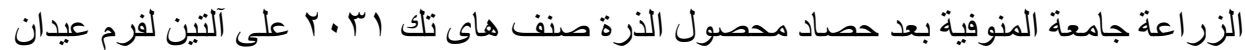
الذرة وانتاج السيلاج احداهما آله الفرم التقليدية والاخرى آلله فرم معدلة بإضافة سير ناقل لعيدان

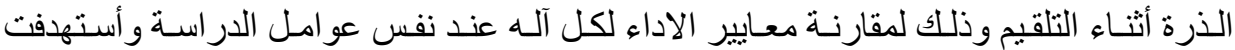

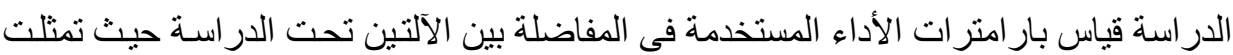
بار اميتر ات الأداء فى قياس وحساب كل فئس من:

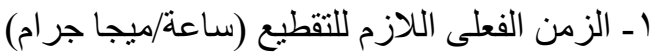

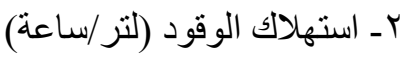
بـ كفاءة القطع (1\%)

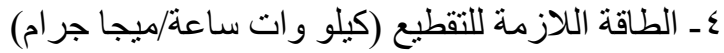
0ـ الإنتاجية (ميجا جر ام/ساعة) وقد أجريت الدر اسة تحت ثناث عو امل بمستو يات مختلفة لكل عامل وهلى

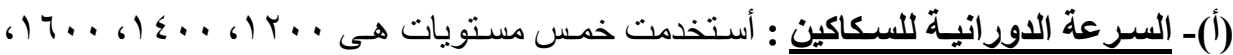
. . \& \& 1 \&..

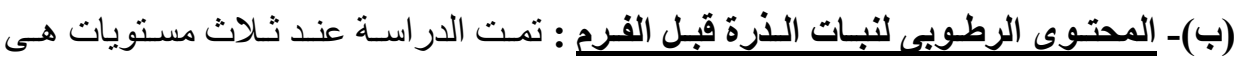
$\% \vee r, \leqslant 0 \& 7 \leqslant, 1960 \leqslant, 11$

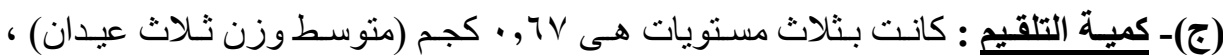

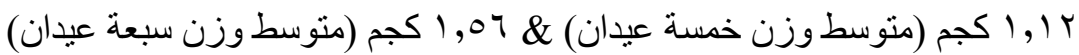

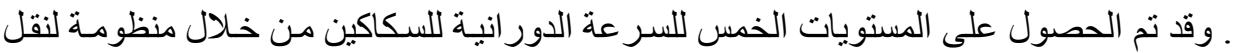

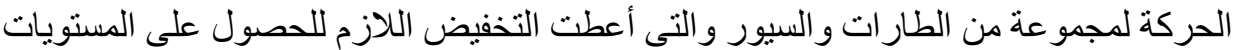
الخمس. وتم قياس هذه السر عة عند كل مستوى بجهاز قياس السرعة الدور انية (tachometer).

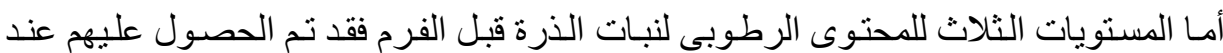

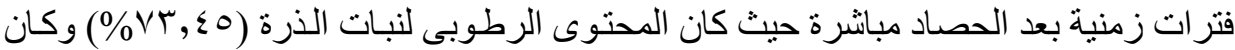

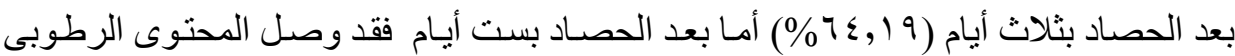

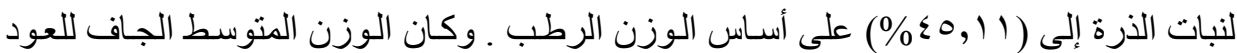
الواحد Y Y, • كجم حيث أستخدم هذا الوزن لحساب كمية التلقيم عند كل مسنتوى من المستويات

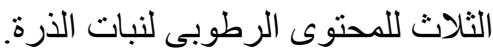




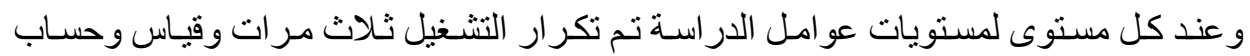
بار امتر ات الآداء السابقة فى كل مكرره و أيضا حساب متوسط القر اءات لكل معاملة.

وتوصلت الار استة الى النتائج الآثية :

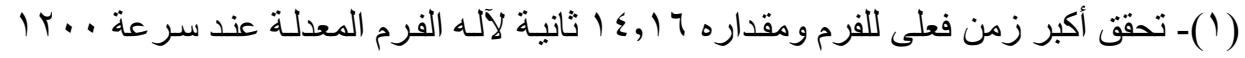

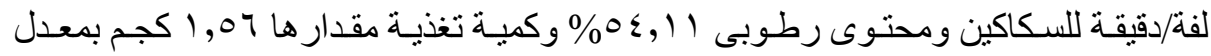

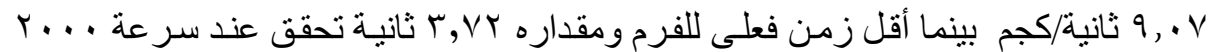

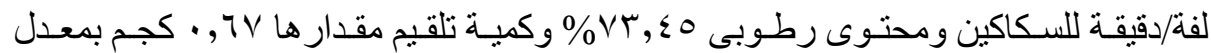

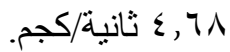

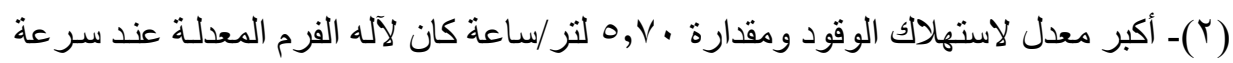

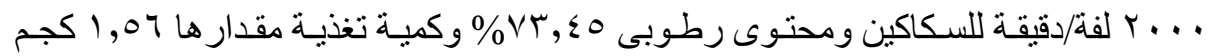

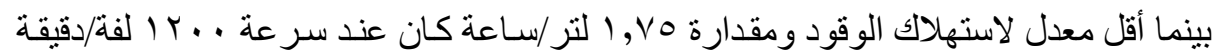

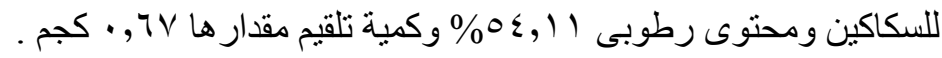

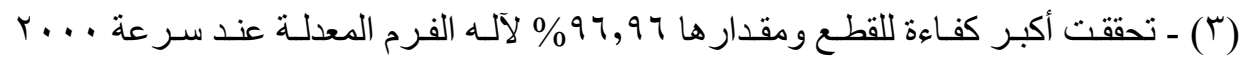

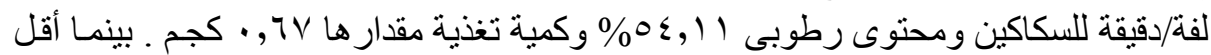

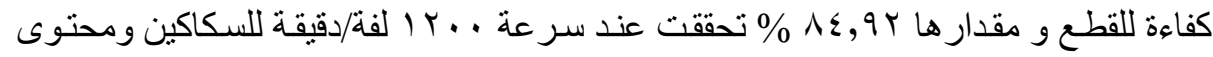

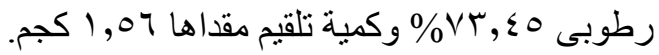

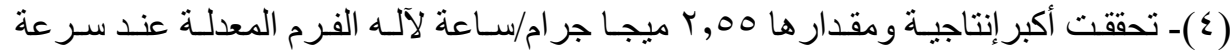

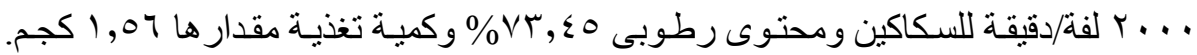

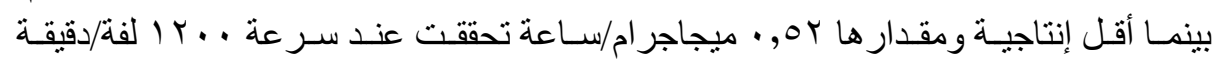

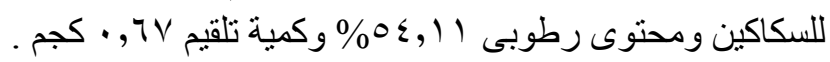

(0) كانت أكبر قيمة للطاقة المستهلكة للفرم Y §, ـ ا كيلووات. سـاعة/ميجا جر ام لآله الفرم

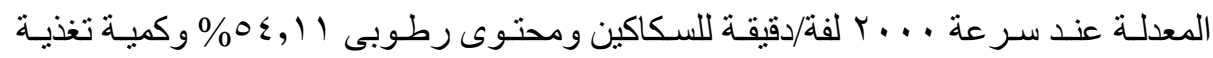

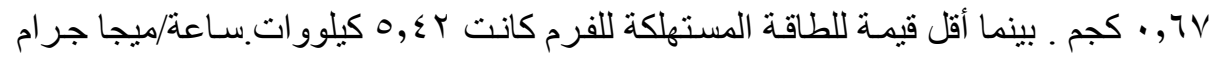

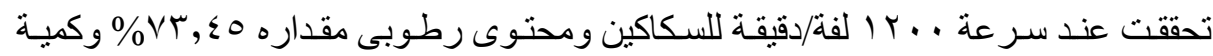
تغذية 1,07 1, 1 كجم. وتوصى الدراسة بالتوصيات الآتيه : (1)- إستخدام آله الفرم المعدله بإضـافه سير ناقل لعيدان الذرة نظر التحقق عناصـر الأمـان لعامل التلقيم وتقليل مخاطر الحو ادث. (Y)- تشغيل آله الفرم المعدله والآله الغير معدله عند كل عو امل الدر اسـة أعطى نتائج منقاربـة لقيمة معدل إستهلاك الوقود.

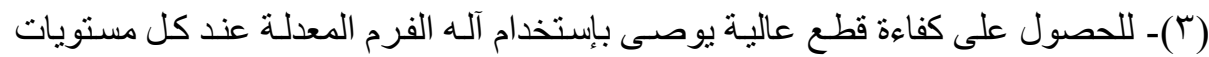
السر عة الدور انية للسكاكين و عند المحتوى الرطوبى عفى المنخفض لعضيد لعيدان الذرة. 